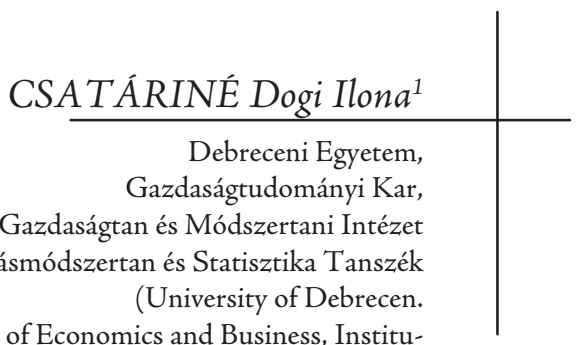

Faculty of Economics and Business, Institute of Sectoral Economics and Methodology,

Department of Research Methodology and Statistics)

\section{AZ ORSZÁGEREDET IMÁZS HATÁSA A HAZAI ÉLELMISZERTERMÉKEK MEGÍTÉLÉSÉRE}

\author{
THE INFLUENCE OF THE COUNTRY OF ORIGIN ON \\ THE IMAGE OF DOMESTIC FOOD PRODUCTS
}

DOI: https://doi.org/10.33567/etm.2248

From the 1960's literature deals more and more with the examination of the country image, mainly due to its influence on the choice/purchase of foreign products (country of origin effect). Most of the publications are linked to marketing science, namely the latest research regards nation image as something that can be positioned on the market, as a product or a brand name.

The aim of my research is to assess the effect of the country of origin on the judgment of domestic foods from the point of view of the Hungarian consumers.

The completed questionnaires were processed using the program SPSS 20. Data were analyzed by factor-and two-step cluster analysis in order to explore the dimensions and clusters.

The analysis showed that the "price" dimension for the country of origin is less determinative in product perception. For this reason if we want to promote domestic products, emphasis should be laid on attractive appearance, on good quality and the reliability of the products, and not necessarily on the favorable price.

Kulcsszavak: országeredet-imázs, fogyasztói magtartás, élelmiszertermék, kétlépcsős klaszterelemzés Keywords: country of origin image, consumer behavior, food, two-step cluster analysis

JEL-kód: M31, F52, Z13

\section{BEVEZETÉS}

A különböző imázsfajták hatása a vásárlók döntéshozatalára régóta jól ismert. A termék származása alapján kialakult kép befolyásolja a termék minőségével és kockázatértékelésével kapcsolatos észleléseket, hatással van a fogyasztói attitűdökre és így végső soron a vásárlási szándékra (Kalicharan, 2014). Olyannyira lényeges szempont ez, hogy a fogyasztók külföldi márkákhoz való hozzáállása, valamint a márkák származásának társadalmi értékelése még a forgalmazókat is befolyásolja, az egyes külföldi márkák adott piacokon való elhelyezésében (Byeong \& Han, 2017).
Ebben a rendkívül globalizált világban és hiperversenyképes üzleti környezetben a származási ország a termékmegkülönböztetés és a versenyelőny megszerzése szempontjából fontos tényezővé vált, de értékes információkkal szolgál a vásárlók számára is (Godey és mtsai,, 2012). Christea, Capatina és Stoenescu (2015) is egyetért azzal, hogy az országeredet mint marketingeszköz használata a fogyasztók és a gyártók szempontjából egyaránt lényeges. Egyrészt a terméktulajdonságok egyre inkább sztenderdizálódnak, a legtöbb termék bárhol és bárki által előállítható, így a gyártóknak alapvető szempont, hogy megfelelö differenciáló tényezőket találjanak termékeik számára. Ilyen tényező lehet a származási hely. Másrészt a fogyasztók azzal a problémával 
szembesülnek, hogy hatalmas a választék, és rengeteg információ áll rendelkezésre a termékekkel kapcsolatban, ami megnehezíti a választást. Az egyre elfoglaltabb vásárlók olyan jelzőket keresnek, amelyek összegezve az információkat, megkönnyítik a választást, és segítenek abban, hogy időt takarítsanak meg, valamint lecsökkentsék a vásárlás során felmerülő kockázati tényezőket (Hámori, 2013).

Számos produktum esetében elmondható, hogy a vevők egyre fontosabb attribútumnak tekintik a származási helyet, különösen az élelmiszertermékek esetében, az élelmiszer-biztonsági előnyök miatt (Beiermann, Ritten, Thunström \& Ehmke, 2017).

$\mathrm{Az}$ országeredet-imázs vizsgálatának jelentőségét mi sem tükrözi jobban, mint az, hogy számos európai országban a nemzeti termékek jelentős előnyt élveznek a beáramló importtal szemben. Ezekben az országokban a fogyasztók tudatos döntését általában valamilyen nemzeti eredetet igazoló jelölési rendszer segíti, amely a termékek országeredetére, valamint minőségére hívja fel a figyelmet (Szakály, Horváth, Soós, Pető \& Szente, 2014). Az országeredet hatása a magyarok fogyasztói magatartásában is megjelenik. Szakály és Polereczki (2009) kutatásukban egyértelműen igazolták, hogy a hazai élelmiszerek pozíciója más országokkal történő egybevetés esetén kedvezőnek bizonyult. A magyar fogyasztók a hazai termékeket - a német és francia termékekkel szemben - szinte minden fontos kategóriában jobb megítélés alá helyezték.

\section{IRODALMI ÁTTEKINTÉS}

Az országeredet imázzsal foglalkozó szakirodalmi bázis közel fél évszázados múltra tekinthet vissza (Papadopoulos, 2004). A származási ország jelentősége - az etnocentrizmushoz hasonlóan -, a globalizáció felerősödésével került a kutatók fókuszába. (Tan \& Farley, 1987) szerint az országeredet hatása a termékmegítélésre az egyik leginkább kutatott terület a fogyasztói magatartáson belül.

\subsection{Az országeredet-imázs definiálása}

$\mathrm{Az}$ országeredet hatásának mélyebb megértéséhez két - a szakirodalomban gyakran összemosódó - fogalmat érdemes elhatárolni, az országimázs (country image) és az országeredet-imázs (country of origin image) fogalmát.

Az országimázs egy adott országról kialakult nézetek, hitek, vélemények összessége, amely kialakulhat spontán, illetve irányított módon is (Kotler, Haider \& Rein, 1993), tehát ez az imázs befolyásolható, alakítható (Fan, 2006). A véleményalkotásra hatással vannak olyan tényezők, mint az adott ország gazdasági és technológiai fejlettsége, politikai helyzete, történelme, kultúrája, hagyományai, valamint kapcsolatai más országokkal (Roth \& Diamantopoulos, 2009). Az országimázs lehet belső és külső imázs. A belső imázs, amit az adott ország lakói gondolnak a saját országukról, a külső imázs pedig, amit a külföldiek gondolnak az adott országról (Hámori, 2013).

Napjainkban a szakirodalom már úgy tekint a nemzetképre (országimázsra), mintha az termék vagy márkanév lenne, amely pozícionálható a piacon.

Az ország imázsa nincs direkt hatással a termékre, hanem közvetetten vonunk le következtetéseket belőle a termékre vonatkozóan. Ezzel szemben az országeredet-imázs az országgal kapcsolatos termékimázs, azaz a fogyasztók általános észlelése az adott országból származó termékekről (Han, 1989). Knight és Calatone (2000) szerint az országeredet-imázs a fogyasztókban kialakult kép az adott ország termékeinek minőségéről és az ott élő emberekről.

Hazánkban Malota és Berács (2007) az országeredet-imázs fogalmát úgy határozta meg, hogy a termék átfogó imázsának az a része, amely a termék adott országból való származása alapján alakul ki. Az országeredet-imázs olyan sztereotípiákból adódik, amelyet a termék iránt azért táplálnak, mert az bizonyos országból származik. Tehát az országeredet-imázs inkább termékimázs, termékre vonatkozik.

\subsection{Az országeredet-imázs mérése, dimenziói}

Az országeredet-imázs mérése több szinten történhet. Mérhető termék- vagy termékkategória-specifikus, illetve általános szinten (az adott ország összes termékére vonatkozóan).

Etzel és Walker (1974) felvetése szerint az általános szintű mérés hibákat rejt, és termékkategóriák szintjén kell vizsgálni az országeredet hatást, mert más lesz az attitüd, ha egyedi termékek vagy termékcsoportok szintjén, vagy ha az adott országból származó termékek globális értékelésén keresztül vizsgálódunk. Három ország és négy termékkategória vizsgálatával igazolták ezt az állításukat.

Hooley, Shipley és Krieger (1988) is egyetértettek ezzel. Véleményüket azzal indokolták, hogy egy adott ország bizonyos termékkategóriában nagyon jó minőségü terméket képes előállítani, míg más termékek esetében nem. Így nem vonhatunk le általános következtetéseket egy adott ország összes termékére vonatkozóan. Főleg, hogy egyes termékek esetében erősebbek lehetnek bizonyos érzelmi reakciók pl. a patriotizmus.

Nincs általánosan elfogadott elmélet arra, hogy melyik szintü mérés a célravezető. A kutatás célját kell figyelembe venni a mérési típus kiválasztásakor (Malota, 2003). Jelen esetben termékkategória-specifikus szinten (élelmiszertermékekre vonatkozóan) vizsgáltam az országeredet hatását.

A kutatás során igyekeztem olyan vizsgálati fókuszt választani, aminek van előzménye a külföldi és a hazai szakirodalomban is. Az országeredet-imázs - az imázsfajtákhoz hasonlóan - nem egydimenziós fogalom, ezt a Malota (2003) által összegyüjtött számos kutatás is bizonyítja: Nagashima, 1997; Cattin, Jolibert, \& Lohnes, 1988; Erickson, Johansson \& Chao, 1984; Han \& Terpstra, 1988; Papadopoulos, Heslop \& Bamossy, 1990; Roth \& Romeo, 1992; Papadopoulos, Heslop \& Bennett, 1993; Cooper \& Calatone, 1997; IKON Research Group, 2000; Berács \& Malota, 2000. Azonban ezek közül csak Papadopoulos, Heslop és Bennett (1993) tanulmánya foglalkozott az adott országra, valamint annak termékeire vonatkozó attitűdök együttes mérésével is. Mivel kutatásom részét képezi a hazánkkal kapcsolatos etnocentrikus érzelmek felmérése is - melynek eredményei a jelenlegi tanulmányban nem kerülnek bemutatásra - így elemzésemhez ezt a skálát (Papadopoulos, Heslop \& Bennett, 1993) tartottam a legalkalmasabb kiindulási alapnak. A skála dimenzióit foglalja össze az 1. számú táblázat. Az első dimenzió, a „Termékhiedelmek” elnevezést kapta, hiszen a termék értékelésével kapcsolatos feltételezésekre irányul. 
A második, „Termékismeret”-nek nevezett dimenzióban a piaci jelenlét van a fókuszban. A harmadik dimenzió a „Termékmegitélés", az ár-érték arány tekintetében tartalmaz állításokat, míg a negyedik dimenzió, a „Vásárlás”, a választ tartalmazza a termékkel kapcsolatban, azaz, hogy vásárolja-e az adott terméket a válaszadó.

1. táblázat: Országeredet-imázs feltételezett dimenziói a Papadopoulos, Heslop és Bennett (1993) által kidolgozott modell alapján

\section{1. dimenzió: Termékhiedelmek \\ Gondos, szakszerű kivitelezés \\ Megbízható \\ Ötletes, innovatív \\ Müszakilag fejlett \\ Jó minőségü \\ Jó szolgáltatás és garancia \\ Vonzó megjelenés \\ Széles választék \\ Nem drága}

\section{2. dimenzió: Termékismeret}

Felismerhető márkanevek

A termékeket jól ismerem

Könnyü hozzájutni

\section{3. dimenzió: Termékmegítélés}

Általában elégedett vagyok ezekkel a termékekkel

Megéri az árát

Büszke lennék, ha ilyen termékeim lennének

Ezek a termékek nekem valók

Megtalálom benne azt, amit venni szeretnék

Mindent egybevetve jó termékek

\section{4. dimenzió: Vásárlás}

Hajlandó vagyok ilyen termékeket venni

Rendszerint sok ilyen terméket veszek

Forrás: Papadopoulos, Heslop E Bennett (1993) alapján

\subsection{Az országeredet-imázs dimenzióinak elkülönítése Ma- gyarországon}

Magyarországon - az országeredet-imázs dimenzióinak feltárását tekintve - a legátfogóbb képet Malota (2003) felmérése adja. 400 fós diákmintán mérte a Papadopoulos, Heslop és Bennett (1993) által kidolgozott skála változóit, hétpontos szemantikus differenciál skálát alkalmazva. Négy ország termékeire vonatkozóan (Németország, Kanada, Magyarország, Csehország) elemezte a hazai és külföldi termékek megítélését. Felmérésében az országeredet-imázs hatását általános szinten - a magyar termékek összességére vonatkozóan - vizsgálta. A kutatásom szempontjából releváns, hazai termékek megítélésére vonatkozó faktoranalízisének eredményeit a 2, táblázat mutatja be.
Malota (2003) öt dimenziót különített el, a dimenziókon belüli állítások a faktorsúlyuk sorrendjében kerültek felsorolásra. Az első dimenzió a „Termékhiedelmek” elnevezést kapta, többségében a magyar termékek értékelésével kapcsolatos állítások kerültek ide. Ez a faktor 37\%-ban magyarázza a teljes szórást. A második dimenziónak „Termékkel való azonosulás” lett a neve, olyan állítások sorolódtak ide, melyekkel a válaszadó a hazai termékekkel kapcsolatos érzelmeit fejezi ki (a faktor által magyarázott szórás: 9\%). A harmadik faktor a „Vásárlás, piaci jelenlét”, amely a márkanév ismeretét, a választékot és a vásárlási szándékot érzékelteti (magyarázott szórás: 7\%) a magyarországi termékeket illetően. A Malota által meghatározott negyedik dimenzió a "Termékismeret”, melyben a hazai termékek ismerete összefüggésbe hozható azzal, hogy könnyen elérhetőek (magyarázott szórás 5\%). Míg az utolsó, ötödik dimenió az „Ár” elnevezést kapta. Ebben az esetben egy, az árra vonatkozó állítás („Nem drága”) képez egy faktort (magyarázott szórás: 5\%). Míg a másik árral kapcsolatos állítás („Megéri az árát") a termékértékeléséhez kapcsolódott mint minőséget mérő változó.

2. táblázat: Az országeredet-imázs dimenziói a magyar termékekre vonatkozóan

$\begin{array}{ll}\text { 1. dimenzió: Termékhiedelmek } & \\ \text { Gondos, szakszerủ kivitelezés } & 0,807 \\ \text { Jó minőségü } & 0,800 \\ \text { Megbízható } & 0,750 \\ \text { Jó szolgáltatás és garancia } & 0,741 \\ \text { Vonzó megjelenés } & 0,741 \\ \text { Ötletes, innovatív } & 0,602 \\ \text { Megéri az árát } & 0,541\end{array}$

\section{2. dimenzió: Termékkel való azonosulás}

Ezek a termékek nekem valók

Büszke lennék, ha ilyen termékeim lennének

Általában elégedett vagyok ezekkel a termékekkel $\quad 0,582$

Müszakilag fejlett

0,553

Hajlandó vagyok ilyen termékeket venni $\quad 0,530$

Mindent egybevetve jó termékek $\quad 0,518$

Megtalálom benne azt, amit venni szeretnék 0,480

\section{3. dimewnzió: Vásárlás, piaci jelenlét}

Felismerhető márkanevek $\quad 0,803$

Széles választék

0,716

Rendszerint sok ilyen terméket veszek

0,617

\section{4, dimenzió: Termékismeret}

A terméket jól ismerem $\quad 0,828$

Könnyü hozzájutni

0,775

5. dimenzió: Ár

Nem drága

0,850 


\section{ANYAG ÉS MÓDSZER}

A szakirodalmak feldolgozását követően primer adatgyüjtést végeztem, melynek keretében egy kérdőíves felmérésre került sor. Kutatásom kezdeti fázisában lehetőségem volt a Debreceni Egyetem Gazdaságtudományi Kar Marketing Tanszékének egy országos reprezentatív kutatásába bekapcsolódni.

Emellett kutatói munkám alapját képezi Malota (2003) kutatása, amely a hazai szakirodalmakat tekintve a legátfogóbb képet nyújtja az országeredet-imázs módszertani vizsgálatát illetően, ezért kutatásom során próbáltam igazodni az általa végzett felmérés módszertanához az összehasonlíthatóság érdekében.

\subsection{A mintavétel}

Az országos primer adatgyüjtés 2014, március 1. és 2014. március 31. között zajlott 1000 fó bevonásával. A mintavétel során az egyes régiók és településtípusok esetében biztosítva volt a reprezentativitás, kvótás mintavétel alkalmazásával.

$\mathrm{A} z$ egyes régiókban kijelölt településeken az úgynevezett véletlen séta (random walking) elve biztosította a teljes véletlenszerüséget a megfelelő válaszadók kiválasztásához. Ezenfelül a felkeresett háztartás lakói közül az úgynevezett születésnapi kulcs alkalmazásával került kijelölésre az interjúra megfelelő személy.

Végezetül a reprezentativitás érdekében a minta többdimenziós súlyozással (nem és kor szerint) lett korrigálva, így a minta négy tényező (régió, településtípus, nem, kor) alapján tükrözi az alapsokaság összetételét.

\subsection{A minta szocio-demográfiai háttere}

A 3. számú összefoglaló táblázat a felmérésbe bevont egyének számát és a különböző szegmentáló tényezők (szocio-demográfiai csoportok és egyéb háttérváltozók) szerinti százalékos eloszlási arányukat mutatja be.
3. táblázat: A minta megoszlása a fontosabb háttérváltozók szerint $(\mathrm{N}=1000)$

\begin{tabular}{|c|c|c|}
\hline \multirow{2}{*}{ Megnevezés } & \multicolumn{2}{|c|}{ A minta megoszlása } \\
\hline & Fö & $\%$ \\
\hline \multicolumn{3}{|c|}{ Nemek szerint } \\
\hline Férfi & 477 & 47,7 \\
\hline Nő & 523 & 52,3 \\
\hline \multicolumn{3}{|c|}{ Életkor szerint } \\
\hline 18-29 év & 213 & 21,3 \\
\hline 30-39 év & 248 & 24,8 \\
\hline 40-49 év & 182 & 18,2 \\
\hline 50-59 év & 196 & 19,6 \\
\hline 60 év felett & 161 & 16,1 \\
\hline \multicolumn{3}{|c|}{ Iskolai végzettség szerint } \\
\hline Max. 8 általános & 111 & 11,1 \\
\hline Szakmunkásképző & 329 & 32,9 \\
\hline Érettségi & 381 & 38,1 \\
\hline Felsőfokú & 179 & 17,9 \\
\hline \multicolumn{3}{|c|}{ Családi állapot szerint } \\
\hline Házas & 421 & 42,1 \\
\hline Élettárssal él & 164 & 16,4 \\
\hline Özvegy & 68 & 6,8 \\
\hline Nőtlen, hajadon & 225 & 22,5 \\
\hline Elvált & 122 & 12,2 \\
\hline \multicolumn{3}{|c|}{ Külföldi utak száma szerint (a 2013. évben) } \\
\hline 1-2 alkalommal & 218 & 21,8 \\
\hline 3-5 alkalommal & 28 & 2,8 \\
\hline $\begin{array}{l}\text { 5-nél több alka- } \\
\text { lommal }\end{array}$ & 30 & 3,0 \\
\hline Egyszer sem & 723 & 72,3 \\
\hline NT/NV & 1 & 0,1 \\
\hline
\end{tabular}

\subsection{Adatgyưjtés és kérdőív}

$\mathrm{A} z$ adatok felvételére a kijelölt válaszadók lakásán került sor, személyes interjúztatás keretében, sztenderd kérdőív használatával. A kérdezőbiztos a kiválasztott személynek egy úgynevezett kártyaszettet adott át, amely tartalmazta az egyes kérdésekre adható válaszlehetőségeket is. A megkérdezett által adott válaszokat a kérdezőbiztos írta be a kérdőívre.

A megkérdezés során alkalmazott kérdőív kérdésblokkjai a következők voltak:

+ Országeredetimázs-skála Papadopoulos, Heslop és Bennett (1993) modellje alapján).

+ Szocio-demográfiai háttérváltozók (nem, kor, iskolai végzettség, családi állapot, jogi helyzet, jövedelmi helyzet, járt-e külföldön 2013-ban?).

Kutatásom célja az országeredet-hatás vizsgálata a magyar élelmiszertermékekre vonatkozóan, ezért a Papadopoulos, Heslop és Bennett (1993) által kidolgozott skála állításai közül el kel- 
lett hagynom három termékértékelési tulajdonságot, mert azok az élelmiszertermékekre nem relevánsak. Ezek a tulajdonságok az alábbiak: „Müszakilag fejlett”; "Jó szolgáltatás és garancia”; "Gondos szakszerű kivitelezés". Emellett a kétértelműség maradéktalan kiszürése miatt hangsúlyoztuk, hogy az állításokat kifejezetten a magyar élelmiszertermékekre vonatkozóan válaszolják meg.

\subsection{Az adatok elemzése}

A kérdőívre adott válaszok feldolgozása az SPSS 20 program segítségével történt. Az adatokat főkomponens- és kétlépcsős klaszteranalízisből álló dimenzió-redukciós technikákkal vizsgáltam, a dimenziók és az egyes klaszterek feltárásához.

A feltáró faktorelemzés-típusok közül azért a fókomponens-elemzést alkalmaztam, mert jelen esetben ismertem az elemezni kívánt változókat (Papadopoulos, Heslop és Bennett (1993) modelljének változói), és minimális információveszteség mellett a lehető legkevesebb faktort szerettem volna létrehozni a legmagasabb varianciahányad elérésével. Az elemzés során Varimaxrotálással végeztem a csoportképzés optimumának elérését.

A klaszterek képzése során kétlépcsős klaszterelemezést alkalmaztam, mely során a távolságmérték megállapításához log-likelihood módszert használtam. A klaszterek számának meghatározásához az úgynevezett BIC-értéket (Schwarz's Bayesian Criterion) vettem alapul az auto-clustering eljárás során. $\mathrm{Az}$ optimális klaszterszámot a BIC-érték változásának és változási arányának alakulása mutatja meg.

\section{EREDMÉNYEK ÉS ÉRTÉKELÉSÜK}

\subsection{Az országeredet-imázs dimenzióinak elkülönítése fakto- ranalízissel}

A mintán végzett faktoranalízis segítségével négy dimenziót sikerült elkülönítenem, az egyes dimenziókhoz tartozó állításokat, valamint azok faktorsúlyát a 4. táblázatban mutatom be. A KMO-mutató értéke 0,940, ami azt jelenti, hogy a változók kiválóan alkalmasak a faktorelemzésre. A Bartlett-teszt $\mathrm{p}<0,001$ értéke alapján erős a korreláció a változók között. A faktorok teljes magyarázott szórása 69,8\%. A faktorok a sajátérték és a magyarázott variancia nagyságának sorrendjében a következők: 1 . faktor: 3,489/23,2\%; 2. faktor: 3,124/20,8\%; 3. faktor: 2,726/18,1\%; 4. faktor: 1,129/7,5\%. Az anti-image korrelációs mátrix MSA-értékei 0,901 és 0,954 között helyezkednek el, vagyis az egyes változók jól beilleszkednek a faktorstruktúrába.

A Papadopoulos, Heslop és Bennett (1993) által felvázolt modell négy dimenziót különít el (1. táblázat). Malota (2003) kutatása során öt dimenziót határozott meg (2. táblázat). Jelen tanulmány a hazai termékeken belül csak az élelmiszertermékek csoportját vizsgálja, így a fent említett kutatások eredményei saját eredményeimmel nem összevethetők, azonban a faktorok kialakításánál mindenképpen iránymutatásul szolgáltak. Saját elemzésem Papadopoulos, Heslop és Bennett (1993) munkásságához hasonlóan négydimenziós faktorstruktúrát eredményezett, azonban a faktorokba került állításokat tekintve Malota (2003) eredményeihez áll közelebb. Az elemzés során egy változó eseté- ben („Megéri az árát”) előfordult, hogy két faktoron is ült, ezért ezt az állítást negligáltam, és újra lefuttattam az analízist.

4, táblázat: Az országeredetimázs-dimenzió a magyar élelmiszertermékek esetében

\begin{tabular}{ll} 
1. dimenzió: Termékhiedelmek & \\
\hline Jó minőségü & 0,770 \\
Vonzó megjelenésű & 0,769 \\
Ötletes, innovatív & 0,740 \\
Megbízható & 0,732
\end{tabular}

2. dimenzió: Termékismeret

Hajlandó vagyok ilyen élelmiszert venni $\quad 0,787$

Mindent egybevetve jó termékek $\quad 0,694$

Ezek az élelmiszerek nekem valók $\quad 0,627$

Rendszerint sok élelmiszert veszek $\quad 0,680$

Általában elégedett vagyok a magyar élelmiszerekkel 0,598

Büszke vagyok arra, hogy ilyen élelmiszert vehetek $\quad 0,468$

\section{3. dimenzió: Termékmegítélés}

Könnyü hozzájutni $\quad 0,784$

A magyar élelmiszereket jól ismerem $\quad 0,673$

Könnyen felismerhető a márkaneve $\quad 0,671$

Széles választék $\quad 0,589$

A magyar élelmiszerek között megtalálom azt, amit venni szeretnék

4. dimenzió: Vásárlás

Nem drága

Az első, a szórást legmagasabb értékkel magyarázó faktor (23,2\%) esetemben is, a „Termékhiedelmek” elnevezést kapta. A termék minőségét mérő változók sorolódtak ide. Ez a termékértékeléssel kapcsolatos dimenzió a fogyasztók szempontjából a legmeghatározóbb, ha a hazai élelmiszerek értékelésére kerül sor. Vezető tulajdonságok a "Jó minőség” és a „Vonzó megjelenés”. Ezeket követték az „Ötletes és innovatív" és a "Megbízható” tulajdonságok.

A második faktorba a termékkel való azonosulással és a vásárlással kapcsolatos állítások tömörültek. Ez a faktor jelentőségét tekintve nem sokkal marad el az első faktortól a magyarázott szórás: 20,8\%. A legnagyobb faktorsúlya $(0,787)$ a „Hajlandó vagyok ilyen élelmiszert venni" állításnak volt, de ide kapcsolódnak olyan állítások is, amelyek a termékkel való azonosulást tükrözik: „Ezek az élelmiszerek nekem valók”; „Büszke vagyok arra, hogy ilyen élelmiszert vehetek”.

A harmadik „Termékismeret” elnevezésű faktor (18,1\%), olyan állításokat foglal magába, amelyek a magyar élelmiszertermékek elérhetőségére („Könnyü hozzájutn””; „Széles választék”), valamint azok ismertségére vonatkoznak („Könnyen felismerhető a márkaneve”). Ide tartozott még egy, a termékkel való azonosulással kapcsolatos állítás is: „A magyar élelmiszerek között megtalálom azt, amit venni szeretnék”. Ez az állítás értelmezhető úgy, hogy megtalálom benne azt, amire számítok (tehát nem csalódom), illetve összekapcsolható a „Széles választékkal" is, miszerint a nagy választéknak köszönhetően megtalálom azt a terméket, amit keresek, ami leginkább hozzám illö. Ha ez utóbbit tekintjük, jobban érthető, hogy miért került ide ez az állítás.

Végül a negyedik faktor az „Ár” elnevezést kapta (7,5\%), mert az 
ár tekintetében hordoz információt. Egy állítás sorolódott ide: „Nem drága”. Ez esetben feltételezhető, hogy a hazai termékekkel társított termékjellemzők (minőség, megbízhatóság) hatására a fogyasztók úgy érzik, ezek a termékek megérik az árukat.

A faktorok kialakítását tekintve elmondható, hogy Papadopoulos, Heslop és Bennett (1993) modelljének „Termékkel való azonosulás” és „Vásárlás” dimenziói esetemben egy faktorba tömörültek, melynek magyarázata az lehet, hogy ha egy adott termék megítélése jó, akkor az a termék vásárlásához vezet. Míg Malota (2003) eredményeihez hasonlóan az „Ár” jelen esetben is külön faktort képez, valószínű, hogy a fogyasztók árérzékenységéből adódik ez az elkülönülés.

\subsection{A háttérváltozók hatásának vizsgálata a termékmegítélésben}

A faktorelemzéssel végzett vizsgálatokat klaszterelemzéssel is kiegészítettem a még pontosabb szegmentálás érdekében. A cél az volt, hogy a sokaságot relatív homogén csoportokba rendezzem a már kialakított faktorok és szocio-demográfiai háttérváltozók szerint. Olyan klaszterek kialakítására törekedtem, melyek elemei a klaszteren belül hasonlóak egymáshoz, azonban minél inkább elkülönülnek a többi klaszter elemeitől.

Első lépésben kiválasztottam 11 változót (faktorok: 4, szocio-demográfiai változók: 7), amelyeket a továbbiakban felhasználtam a klaszterek kialakításához. Ezt követően kétlépcsős klaszterelemezést alkalmaztam. Gaskin (2012) ajánlása alapján a távolságmérték megállapításához log-likelihood módszert használtam, majd a klaszterek számának meghatározásához az úgynevezett BIC-értéket (Schwarz's Bayesian Criterion) vettem alapul az auto-clustering eljárás során. $\mathrm{Az}$ optimális klaszterszámot a BIC-érték változásának és változási arányának alakulása mutatta meg. Ez alapján a négyklaszteres megoldást választottam. A klaszterek között az összes háttérváltozó alapján találtam szignifikáns eltérést. Az egyes klaszterek az alábbiak szerint jellemezhetők.

Az első klaszterben (172 fö) a minta egészéhez viszonyítva egy fiatalabb korosztály képviselteti magát (30 év alattiak), akik családi állapotukat tekintve még nem kötelezték el magukat, nőtlenek/ hajadonok. Legmagasabb iskolai végzettségüket nézve többségében érettségivel rendelkeznek, valamint jogi helyzetük alapján jellemzően GYES/GYED-en lévők. Jövedelmekröl úgy nyilatkoztak, hogy éppen elegendő ahhoz, hogy megéljenek belőle, félretenni azonban már nem tudnak. 2013-ban egyszer sem jártak külföldön. Termék megítélésüket leginkább a „Termékhiedelmek” dimenzió befolyásolja, azaz fontos számukra a termék vonzó megjelenése, jó minősége, valamint, hogy ötletes, innovatív és megbízható legyen.

A második és egyben legnagyobb klaszter (384 fö) a középkorosztályt (30 és 50 év közöttiek) foglalja magába, akik többségében férfiak és élettárssal élnek. Iskolai végzettségüket tekintve szakmunkás/szakiskola hallgatói voltak. Aktív szellemi dolgozóként tevékenykednek, és jövedelmüket éppen elégnek tartják ahhoz, hogy megéljenek belőle, de az első klaszterhez hasonlóan félretenni már nem tudnak belőle. 2013-ban egyszer-kétszer jártak külföldön. Ezt a klasztert szintén a „Termékhidelmek” dimenzió elemei befolyásolják legnagyobb mértékben, ha a termékértékelésről van szó.

A harmadik klaszter (246 fö) nagyon hasonló a második klaszterhez, hiszen többségében középkorúak (30-50 év) tartoznak ide, akik élettárssal élnek, és aktív szellemi dolgozók. Azonban a minta egészéhez viszonyítva inkább nők tartoznak ide, akik már felsőfokú végzettséggel rendelkeznek. Jövedelmi helyzetükre úgy tekintenek, hogy elegendő ahhoz, hogy megéljenek belőle, és keveset félre is tudnak tenni, azonban többségük ennek ellenére egyszer sem utazott külföldre 2013-ban. Ráadásul ezt a klasztert befolyásolja leginkább az "Ár" a termékmegitélés során.

A negyedik klaszter (189 fó) egy idősebb (50 év felettiek) és jogi helyzetét tekintve nyugdíjas generációt takar. A teljes sokaságra vetítve, túlnyomórészt szakmunkást vagy szakiskolát végzettek tartoznak ide. Többségük jövedelme éppen elegendő ahhoz, hogy megéljenek belőle, azonban félretenni már nem tudnak. Ennek ellenére a klaszter nagy része egyszer vagy kétszer járt külföldön 2013-ban. Több kutatás is igazolta, hogy az idősebb korosztály erősebb patrióta érzelmeket táplál. Ezt igazolja jelen kutatásban az is, hogy erre a klaszterre a „Termékkel való azonosulás, vásárlás” dimenzió hat leginkább a termékmegítélés során („Ezek az élelmiszerek - magyar élelmiszerek nekem valók”; „Büszke vagyok arra, hogy ilyen - magyar - élelmiszert vehetek").

\section{KÖVETKEZTETÉSEK, JAVASLATOK}

A faktoranalízis eredményeit tekintve megállapítható, hogy a dimenziók közül a „Termékhiedelmek”-kel kapcsolatos tulajdonságok a legmeghatározóbbak, (magyarázott szórás: 23,2\%). De nem sokkal maradnak el a „Termékkel való azonosulás, vásárlás”, valamint a "Termékismeret” dimenziók sem (20,8\%; 18,1\%), ami azt jelenti, hogy ezek is egyre fontosabb szemponttá válnak a termékmegitélés során. Az „Ár” szintén külön dimenzióként jelenik meg, bár csak alacsony részét (7,5\%) magyarázza a teljes szórásnak. Ez arra enged következtetni, hogy ha az országeredet szempontjából vizsgáljuk a hazai élelmiszerek fogyasztói megítélését, akkor a termék ára befolyásoló, de kevésbé meghatározó szempont a termékválasztásnál, inkább a minőségi szempontok kerülnek előtérbe.

A klaszterelemzés eredményei párhuzamba vonhatók a faktoranalízis eredményeivel. Arra a megállapításra jutottam, hogy - bár a magyar fogyasztók gyakran híresek az árérzékenységükről - a négyből három klaszternél az ár nem befolyásolja a termékmegitélést, ha az országeredetről van szó. Az országeredet inkább a termékek minőségi értékelését, a termékkel való azonosulást befolyásolja nagymértékben.

Ebből kifolyólag, ha szeretnénk, hogy a hazai termékeket kedvezően ítéljék meg, akkor a termékek vonzó megjelenésére, jó minőségére, megbízhatóságára kell a hangsúlyt fektetni és nem minden esetben a kedvező ár hangsúlyozására.

\section{6. ÖSSZEFOGLALÁS}

Kutatásom fő célkitűzése az volt, hogy számszerüsítsem az országeredet-imázs hatását a hazai élelmiszertermékek megítélésére a magyar fogyasztók aspektusából.

Munkám kezdeti fázisában lehetőséget kaptam, hogy a Debreceni Egyetem Gazdaságtudományi Kar Marketing Tanszékének egy országos reprezentatív kutatásába bekapcsolódjak. Az országos primer-adatgyüjtés 2014. március 1. és 2014. március 31. között zajlott 1000 megkérdezett bevonásával. A kérdőívre adott válaszok feldolgozása az SPSS 20 program segítségével történt. Az adatokat főkomponens- és kétlépcsős klaszteranalízisből álló dimenzió-redukciós technikákkal vizsgáltam a dimenziók és az egyes klaszterek feltá- 
rásához. Négy dimenziót sikerült elkülönítenem: „Termékhidelmek”, „Termékkel való azonosulás, vásárlás”, „Termékismeret”, „Ár”. Ezzt követően kétlépcsős klaszteranalízis segítségével a vizsgálatba bevont háttérváltozók (szocio-demográfiai tényezők) hatását vizsgáltam. Négy klasztert határoltam el. Az elemzésből kiderült, hogy az „Ár” dimenzió az országeredet vonatkozásában kevésbé meghatározó a termékmegitélés során.

\section{IRODALOM}

Beiermann, J., Ritten, C., Thunström, L. \& Ehmke, M. (2017). Measuring the value of information - revealed preferences for country of origin information. Journal of Behavioral and Experimental Economics, 71, 96-104. doi: 10.1016/j.socec.2017.10.002

Berács, J. \& Malota, E. (2000). Fogyasztói etnocentrizmus - az etnocentrizmus és az országeredet imázs kapcsolata a termékválasztásban. Vezetéstudomány, 21(2), 25-38.

Byeong, J. \& Han, M. (2017). Country of origin effects in international marketing channels: How overseas distributors account for the origins of products and brands. International Marketing Review, 34(2), 224-238. doi:10.1108/IMR-03-2015-0073

Cattin, P., Jolibert, A. \& Lohnes, C. (1988). An American vs. French Cross-Culural Study of Five „Made in” Concepts. Journal of International Business Studies, 13(3), 131-141.

Christea, A., Capatina, G. \& Stoenescu, R. (2015). Country-of-Origin Effects on Perceived Brand Positioning. Procedia Economics and Finance, 23, 422-427. doi:10.1016/S2212-5671(15)00383-4

Cooper, A. \& Calatone, R. (1997). The Dimnsinality of Country Image: A Confirmatory Analysis. Marketing Theory and Practice, 8, 275.

Erickson, G., Johansson, J. \& Chao, P. (1984). Image variables in multi-attribute product evaluation: Country-of-origin Effects. Journal of Consumer Research, 11(2), 694-699.

Etzel, M. \& Walker, B. (1974). Advertising strategy for foreign products. Journal of Advertising Research, 14(3), 41-44.

Fan, Y. (2006). Branding the nation: What is being branded? Journal of Vacation Marketing, 12(1), 5-14. doi: 10.1177/1356766706056633

Gaskin, J. (2012). Two-step Cluster Analysis in SPSS. Forrás: StatWiki: http://statwiki.kolobkreations.com/index.php?title=Cluster_Analysis

Godey, B., Pederzoli, D., Aiello, G., Donvito, R., Chan, P., Oh, H., Singh, R, Skorobogatykh, I. I., Tsuchiya, J. \& Weitz, B. (2012). Brand and country-of-origin effect on consumers' decision to purchase luxury products. Journal of Business Research, 65(10), 1461-1470. doi:10.1016/j.jbusres.2011.10.012

Hámori, J. (2013). Az etnocentrizmus érvényesülése a fogyasztói döntéseknél az élelmiszerek piacán. [PhD-értekezés]. Gödöllő: Szent István Egyetem Gazdálkodás és Szervezéstudományok Doktori Iskola.

Han , C. \& Terpstra, V. (1988). Country-of-Origin Effects for Uni-National and Bi-National Products. Journal of International Business Studies, 19(2), 235-255. doi: 10.1057/palgrave.jibs.8490379

Han, C. (1989). Country Image: Halo or summary construct? Journal of Marketing Research, 26(2), 222-229. doi:10.2307/3172608

Hooley, G., Shipley, D. \& Krieger, N. (1988). A Method for modelling consumer perceptions of country of origin. International Marketing Review, 5(3), 67-76. doi:10.1108/eb008359

IKON Research Group. (2000). Evidence of Home Country Bias in
Evaluation of Products: A 15-Country Study. Rotterdam: 29th EMAC Conference.

Kalicharan, H. (2014). The effect and influence of country of origin on consumers' perception of product quality and purchasing intentions. International Business and Economics Research Journal, 13(5), 897902.

Knight,G.\&Calatone, R.(2000).Aflexiblemodel of consumercountry-of-otigin perceptions: A cross-cultural investigation. International Marketing Review, 17(2), 127-145. doi:10.1108/02651330010322615

Kotler, P., Haider, D. \& Rein, I. (1993). Marketing places: Attracting Investment and tourism to cities, states and nations. Free Press.

Malota, E. (2003). Fogyasztói Etnocentrizmus. A sztereotípiák, az etnocentrizmus és az orszégeredet imázs hatása a hazai és a külföldi termékek megítélésére. [PhD-értekezés]. Budapest: Budapesti Közgazdaságtudományi és Államigazgatási Egyetem, Marketing Tanszék.

Malota, E. \& Berács, J. (2007). A fogyasztói etnocentrizmus új kkoncepcionális modelljének kialakítása és verifikálása. Vezetéstudomány, 38(3), 28-39.

Nagashima, A. (1997). A Comparative „Made In” Product Image Survey Among Japanese Businessmen. Journal of Marketing, 41(3), 95-100. doi: 10.2307/1250943

Papadopoulos, N. (2004). Place Branding: Evolution, Meaning and Implications. Place Branding, 1(1), 36-49. doi:10.1057/palgrave. pb.5990003

Papadopoulos, N., Heslop, L. \& Bamossy, G. (1990). A comparative image analysis of domestic versus imported products. International Journal of Research in Marketing, 7(4), 283-294. doi: 10.1016/01678116(90)90005-8

Papadopoulos, N., Heslop, L. \& Bennett, D. (1993). National image correlates of product stereotypes: A study of attitudes towards east european countries. European Advances in Consumer Research, 1, 206-213.

Roth, K. \& Diamantopoulos, A. (2009). Advancing the country image construct. Journal of Business Research, 62(7), 726-740. doi:10.1016/j.jbusres.2008.05.014

Roth, M. \& Romeo, J. (1992). Matching Product Category and Country Image Perceptions: A Framework for Managing Country-of-Origin Effects. Journal of International Business Studies, 23(3), 476-497. doi: 10.1057/palgrave.jibs.8490276

Szakály, Z* \& Polereczki, Z* (2009). A fogyasztói etnocentrizmus vizsgálata Magyarországon. Holstein Magazin, 17(6), 20-22.

Szakály, Z., Horváth, A., Soós, M., Pető, K. \& Szente, V. (2014). A minőségre és származásra utaló jelölések szerepe a fogyasztói döntéshozatalban. Élelmiszer, Táplálkozás és Marketing, 10(1), 3-10.

Tan, C., \& Farley, J. (1987). The impact of cultural patterns on cognition and intention is Singapore. Journal of Consumer Research, 13(4), 540-544. doi:10.1086/209087 